\title{
Framing the Sources of Image of a Local Area through Outcome-Based Dynamic Performance Management
}

\author{
Vincenzo Vignieri ${ }^{1}$
}

(C) Springer Science+Business Media, LLC, part of Springer Nature 2018

\begin{abstract}
This article investigates the place image concept. It aims to frame major factors impacting on the image of a local area and to suggest associated measures. The adoption of a dynamic approach enables the exploration of four major factors: the level of tourism development, the fit of contextual attributes, the strength of identity, and the level of synergy between public and private sectors. The emerging conceptual model identifies twelve performance indicators driving interdependencies between outputs and outcomes. Such a model eventually is applied to the "Taormina-Etna district" located in Sicily (Italy) - with the intent to discussing its effectiveness.
\end{abstract}

Keywords Local Area Image - Outcome-based Dynamic Performance Management • System Dynamics · Taormina-Etna district

\section{Introduction}

It is important to understand the processes that lead to local area success. National or local "prosperity is created, not inherited [...] nations have become more, not less, important" (Porter 2011: 1). Nations, regions, cities and local areas compete on a global scale (Begg 1999; Cavenago and Trivellato 2010; Porter 1995); and governments increasingly recognize that they require a new way of assessing identity and strategies, if they want to prosper sustainably. Ever since domestic firms have been looking to expand their markets overseas, country image has become a crucial success factor. Governments are called to manage their country reputation and local areas institutions have to act alike, if they want to attract business ventures and tourists or to export local products.

Vincenzo Vignieri

vincenzo.vignieri@unipa.it

1 Department of Political Sciences and International Relations, University of Palermo, Palermo, Italy 
Managing the image of a local area entails the challenge to first, frame the sources of that image, secondly, understand what the driving factors are, and thirdly, identify some leverage points suitable for sustainable public policies. It demands for an outcomebased performance management system which allows decision-makers to measure the "output" or the amount of products and services completed or delivered, as well as to capture the "outcome," the results or the consequences of service delivery that are important to the public (Ho and Ni 2005). "Outcomes or effects, intended or unintended, gross or net, are everything beyond outputs. Since effects or outcomes are realized by a range of organizations, public sector performance measurement systems should not just be organized at the individual organizational level but at the level of a policy field or a product/service chain as well” (Bouckaert and Halligan 2007: 16).

The majority of studies about place-image relationships point at the national level and focus on marketing. A common explanation lies in the fact that the image of a country is not under the marketer's control - unlike product or in corporate brand - but it has a big impact. "In fact, there remains much misunderstanding and many commentators and some consultants and academics still interpret 'place branding' as simply the application of product promotion, public relations, and corporate identity activities for countries, cities, or regions, as though they are mere commodities" (Morgan et al. 2004: 1).

As Matarazzo (2012: 38) pointed out, despite a significant amount of works published in the field, only a few scholars have addressed the country image from a managerial and institutional perspective. Moreover, there is a paucity of studies using qualitative techniques; in fact, they have mostly employed quantitative approach by which to measure a limited set of categories resulting in a lack of explanatory research.

This paper aims to explain the sources of the image of a local area, through a case study. To this end, the paper applies an inter-institutional outcome-based Dynamic Performance Management (DPM) perspective to understand what are the driving factors of the image of a tourism destination. DPM is an approach that applies System Dynamics (SD) methodology (Forrester 1961; Forrester 1969; Sterman 2000) to performance management systems (Bianchi 2016).

The structure of the paper is the following: after the introduction, the second section investigates the concept of place image, and also provides a literature review. It discusses the relevant theoretical frameworks, highlighting their major limitations. In light of those limitations, section 3 argues the case for an outcome-based inter-institutional approach, and section 4 outlines the DPM approach. Section 5 introduces the case study "Taormina-Etna district," compares the district's results with the overall performance of the local area, identifies performance drivers and proposes measures. Section 6 discusses the DPM chart and reveals managerial evidence. The concluding section elucidates implications of the findings and outlines policy suggestions.

\section{On Place Image}

Places, like brands, have an image. For business, the marketing department influences products and brand image. The latter, "represents a promise of value and performance, incite beliefs, evoke emotion and inspire behaviors" (Kotler and Gertner 2011: 35), it enhances the perceived utility of a product and customers are willing to pay higher prices. 
For places managing their image is not an easy task. It is "the sum of beliefs and impressions people have about places. Image represents a simplification of a large number of associations and pieces of information connected with a place. They are a product of the mind, trying to process and pick out essential information from huge amounts of data about a place" (Kotler et al. 1993: 14). Place image represents knowledge structures related to places, which are long-lasting and difficult to change (Morgan et al. 2004). Place image is "the total of all descriptive, inferential and informational beliefs one has about a particular country (Martin and Eroglu 1993: 193). Images represent a simplification of a large number of associations and pieces of information connected with a place (Gertner and Kotler 2004).

The relationships between image and place have been investigated traditionally at a country level. However, during the last few years, a growing body of research focusing on a more localized scale is emerging. There have been two important constructs used in place image studies. This literature distinguishes them as the "Country of Origin Effects" (CoO), and the "Competitive Identity".

\section{"Country of Origin Effects"}

The "Country of Origin Effects" represents the influence - either positive or negative that the country of origin of a product has on consumer behavior (Bursi and Galli 2012). Academic interest in $\mathrm{CoO}$ was initiated in 1965 in an article of Schooler (Andéhn and Berg 2011). Many studies pointed out that the place image represents an "extrinsic cue" (Dinnie 2004; Peterson and Jolibert 1995; Roth et al. 2008; Verlegh and Steenkamp 1999) that, like the price and qualitative characteristics of the product, can influence the choice behavior of consumers (Bertoli and Resciniti 2013). Then, the tight association of a brand(s) or product(s) with a "made in" label can determine its success (Bursi and Galli 2012).

Two formulations classify the CoO: halo and summary effects (Han 1989). The halo effect is the influence made by the country of origin on consumers' purchase intention when there is a lack of experience with a given product. Potential customers evaluate products using their perceived country image; that rely on the general knowledge they have about the country itself, including its people, and its level of economic, political and social development. Han (1990), testing the role of country image in consumer choice behavior, suggested that country image may be more important in the evaluation of brands from a familiar country, rather than from an unfamiliar country. This because consumers are more likely to have confidence in the quality of products from the country they have had more experience with. "Consumers may tend to infer specific attributes of a country's products by their overall perception of the country image" (Matarazzo 2012: 30). As the causal model developed by Han $(1989,1990)$ has demonstrated, through country image, consumers may develop an attitude toward a brand. Therefore, their purchase intentions mature. The halo effect has the following relationship:

\section{Country Image $\rightarrow$ Beliefs $\rightarrow$ Brand attitude}

Summary effect takes place when consumers are unfamiliar with a product from a particular country, but they have experiences with other products from the same 
country. Hence, consumers may use their experiences, as well as mass media information or word-of-mouth, to develop an attitude toward that product (Johansson 1989). Han (1990) clarified that when it comes to the summary construct, consumers derive a country image from products information about product attributes.

\section{Beliefs about product $\rightarrow$ Country Image $\rightarrow$ Brand attitude}

The two effects are highly connected (Bursi and Galli 2012). Fruchter et al. (2006) presented a dynamic model that includes both halo and summary constructs. Without product familiarity, the country image affects the purchase decisions. After purchases, consumers mature experiences with products that allow them to adjust the country image according to the recent experience. The more the country image relies on the most recent experiences with products, the more it works as summary (Bursi and Galli 2012). "The direct effect of country image reflects its use as a summary construct, while the indirect effect, through product beliefs, represents consumers' use of country image as a halo" (Matarazzo 2012: 32).

Studies on $\mathrm{CoO}$ have investigated the consumer perspective as well as the implications for firms. The latter studies focus on how the $\mathrm{CoO}$ cue can benefit firms associated with countries possessing positive product-country image. Roth and Romeo (1992) stated that country image is product specific and it requires a match between product features and country image dimensions. This evidence has big implications for firms since managers can select or omit specific product or country information in their marketing communications according to this favorable and unfavorable match.

Papadopoulos and Heslop (1993) criticized the concept of CoO because it assumes a single place of origin for a product when it is common that a product may well be manufactured in one country but designed, assembled, branded in one or different countries. They proposed the term "Product-country Image" (PCI) and suggested firms highlight the country image suitable for their target markets.

\section{Place Image as "Competitive Identity"}

A significant contribution to the study of country image is the work of Simon Anholt, whose framework regarding the issue is called competitive identity theory (Anholt 2007). At the core of the theory, there is the idea that countries (and, by extension, cities, and regions too) are "judged by what they do, not by what they say. The notion that a country can simply buy its way into a better reputation has proved to be a pernicious and surprisingly resilient one. The national image has more to do with domestic and regional identity, politics and economics of competitiveness than with branding as it is usually understood in the commercial sector" (Anholt 2011: 21).

Although places do have brand images, they are not primarily about marketing, as it has often been assumed. Place image is a perception and it does not reside in the municipality or tourist agencies' offices. It exists in the mind of the people; it is stored in a remote location, hence talking about the image of a place means to manage the attributes of this location and then the story told through media about this location (Kotler et al. 1978). 
According to Anholt's perspective, the most valuable asset for a country is the name of the country itself, which evokes its image. Governments, local administrations, and entrepreneurs - only to mention a few - are called to manage the world's perception of their place image and to develop a strategy for managing it.

Anholt developed a model which incorporated six areas of activities that a country should address to build a strong place image (fig. 1).

The six dimensions are the following:

- tourism promotion activity as well as the experiences in visiting the place function as word-of-mouth mechanisms in influencing the image of place.

- The products exported - they are ambassadors of a place; they communicate its value and tradition.

- Policy, which reflects the political decisions as media report them as well as how they influence domestic activities.

- The method used by a place to attract investments like businesses, human resources or foreign companies.

- Cultural exchange and activities. The international events a place hosts as well as the exports of local heritage through the museums, bands, and theaters.

- How inhabitants behave abroad and the way in which they treat the visitors to their country, as well as the most famous people who live there.

The basic theory behind the hexagon is: for decision-makers to build a positive image, they have to develop a clear idea of what a place is and stands for and then they have to manage and coordinate all the six points of the hexagon.

What Anholt's approach emphasizes is that place image can be neither built nor changed through communication: it is not a marketing concern and communication may help only in spreading what a country makes and does. To build and manage a strong competitive identity, local decision-makers need to develop a "strategy" (goals), to create real "substance" (implementation actions) and do not overlook "symbolic actions" (communication) (Anholt 2011: 28).

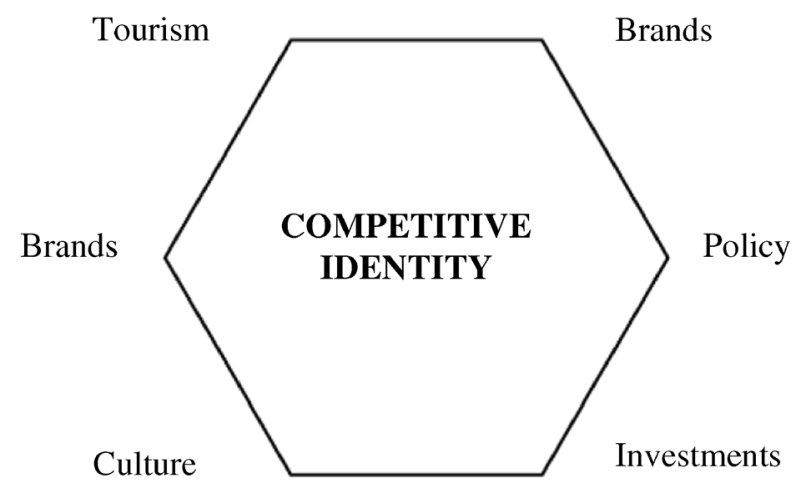

Fig. 1 The hexagon of Competitive Identity (Anholt 2006: 26) 


\section{"CoO" and Competitive Identity Limitations}

The concept of $\mathrm{CoO}$ communicates the effects the image of a place has on consumer behavior as well as the implication for firms that want to exploit its effect. What $\mathrm{CoO}$ studies are not able to explain is how a place can build such an image.

Even though the "Competitive Identity" hexagon tries to create a systemic way of looking at the image of an area, the research used statistical techniques that are suitable for cross-national comparative analysis through indexes, but they are not able to explain the underlying causes of place's image dynamics.

The image of a local area does not rely only on what various public institutions do, but it is a multifaceted, synthetic, result of the overall geographic area including different institutions, public and private organizations, citizens, and firms too.

A local area is a characterized by a dynamic environment where public organizations are loosely coupled (Bianchi 2012, 2016; Borgonovi 2002; Meyer 2002; Meyer and Scott 1983; Scott 2003; Weick 1976): i.e. municipalities, as well as regional administration, are in charge of promoting tourism in the area, but they operate without any strategic alignment. There is a weak coordination in the interplay between public and private actors' strategies that lead to high degree of fragmentation of development policies. There are significant delays between policy adoption and related effect because the latter quite often depends on the availability of funds from the European Union and the investments lag behind formal decisions (Bianchi 2010a). Furthermore, each decision-maker operates in a silos because "the capacity of the human mind for formulating and solving complex problems is very small compared with the size of the problem whose solution is required for objectively rational behavior in the real world or even for a reasonable approximation to such objective rationality" (Simon 1957: 197).

To frame the sources of a local area image, it is necessary to broaden and enhance the standpoint, embracing an inter-institutional outcome-based perspective.

\section{The Need for Inter-Institutional Approach in Framing the Sources of Image of a Local Area}

A local area needs to manage its image actively if it wants to pursue sustainable development. Local actors are called to attract and retain strategic resources, such as investments, public funds, infrastructures, companies, population, human capital, tourism, arts, and global events (Bianchi and Tomaselli 2015). "Places compete in attracting visitors, residents, and businesses [...] a place with a positive reputation finds it easier to vie for attention, resources, people, jobs and money; a positive place reputation builds place competitiveness" (Morgan et al. 2012: 3). Public and private organizations need to discover what the perception of their place is, and to develop a strategy for managing it. This implies consideration of a systemic approach according to which the performance of a local area lies behind the capability of both sectors to generate value individually (Bianchi 2010b). It requires coordination and an outcome perspective when assessing policies' impact on performance and sustainability.

It is necessary to blend span and depth of performance to make decision-makers aware of the system's key variables' behavior when it comes to designing policies aimed at fostering sustainable growth in a local area. In other words, it is required to 
integrate inputs, activities, outputs and effects/outcomes with strategic and operational objectives, at the organizational level (micro), at the policy level (meso) and interinstitutional level (macro) (Bianchi 2010b). The objectives derive from an environment whose structure influences the outcomes for the local area, and in turn its generation is essential for the overall system's development as well as to raise sufficient resources (Anselmi 2014; Bianchi 2004; Borgonovi 2002) to maintain it. This integration results in a dynamic and variable span and depth of a performance platform for control (Bouckaert and Halligan 2007).

At the inter-institutional level, the interaction among policies of different institutions strongly influences performance. The advantages to adopt an inter-institutional perspective is to capture the outcomes, as achieved by the broader context of the local area. Such a point of view could be defined as external, meaning that a "formal model can be considered to be objective instances of a reality domain" (Größler 2010: 385) since it does not reflect the observation point of a specific decision-maker. If one takes this perspective, it is possible to draw the boundaries of the system around a local area, where resources, capabilities, and management processes collectively interact and behave (Morecroft et al. 2002). "Like all systems, the complex system is an interlocking structure of feedback loops" (Forrester 1969: 107) that represents the environment surrounding any decision point in a system (Forrester 1992). Therefore, the behavior of a system arises from its structures (Davidsen 1991; Wolstenholme 1990). Complex systems are characterized by a high levels of dynamic complexity (Sterman 2000: 22), bounded rationality in decision making process (Simon 1957) and misperceptions of feedbacks (Moxnes 2004; Sterman 1989) that led people to adopt an event based mental model and an open loop causality map (Morecroft 2015). "The robustness of the misperceptions feedback and the poor performance they cause are due to two basic and related deficiencies in our mental model" (Sterman 2000: 27).

$\mathrm{SD}$ is a model-based methodology grounded in "Information-Feedback Control Theory" (Forrester 1961: 14), it aims to observe and to identify the problematic behavior of a system and to create a validated representation (or model) of the system under investigation (Wolstenholme 1990: 2). Indeed, it has been widely used to cope with the dynamic complexity of systems. Useful, reliable, validated, and effective simulation models (Lane 1995; Senge and Forrester 1980) help to develop the learning process of decision-makers and support them in policy design. This because SD models are capable of reproducing the existing system behavior and facilitating the design of an improved policy.

Social systems cannot be modelled in a way that captures their entire complexity because "all models are simplifications of reality. If this were not the case, their usefulness would be diminished" (Ackoff 1977: 2). SD models aim at producing "qualitative statements about modes of behavior, appropriate performance indicators and effective leverage points" (Lane 2012: 591). Insight SD modelling is an established practice used to inform the understanding of processes (Bianchi and Tomaselli 2015; Ghaffarzadegan et al. 2011) and depends heavily on graphic demonstration (Wolstenholme 1999).

DPM by combining SD methodology with performance management systems enriches the perception of the investigated problematic behavior. DPM through conceptual models identifies the structure behind problems and enhance the understanding of the causal connection of a given time development. 


\section{A Dynamic Performance Management Approach to Frame the Sources of the Local Area Image}

A local area's development is highly affected by image improvement. Thus there is a need for a holistic methodology able to frame and assess system's outcomes. As Bianchi (2012: 149) pointed out "conventional financially focused P\&C systems have been considered lacking in relevance since they are not able to provide information that can support either dynamic complexity management, the measurement of intangibles, the detection of delays and to deal with the sustainable growth".

According to Bianchi and Rivenbark (2012: 10), the growth can be sustainable if the rate at which end-results change the endowment of corresponding strategic resources is balanced. By taking this perspective, the accumulation and depletion processes of shared strategic resources strongly influence the local area's performance, which is greater than the sum of the specific performance of each comprised organization.

To manage a local area's performance, it is crucial to define firstly what performance is and secondly what are the key success factors driving such a performance. Figure 2 shows the relationship between strategic resources, performance drivers and end-results Fig. 3.

DPM requires that end results be explicit. Consequently, it is necessary to identify performance measures related to both end-results and linked performance drivers. Drivers represent those measures able to capture, explain, cause, and fuel the end results. Ratios measure performance drivers (i.e. as a ratio between an organization or a local area's performance and a benchmark, or target). The numerator of a performance driver is the current state of performance, while the denominator is the benchmark value. As fig. 2 shows, decision-makers have to act on the upstream strategic resources level, if they want to affect performance drivers and, in turn, end-results. Is through the end-results that they can build up, preserve, and deploy strategic resources. Managing strategic resources to affect both performance drivers and end-results in accordance

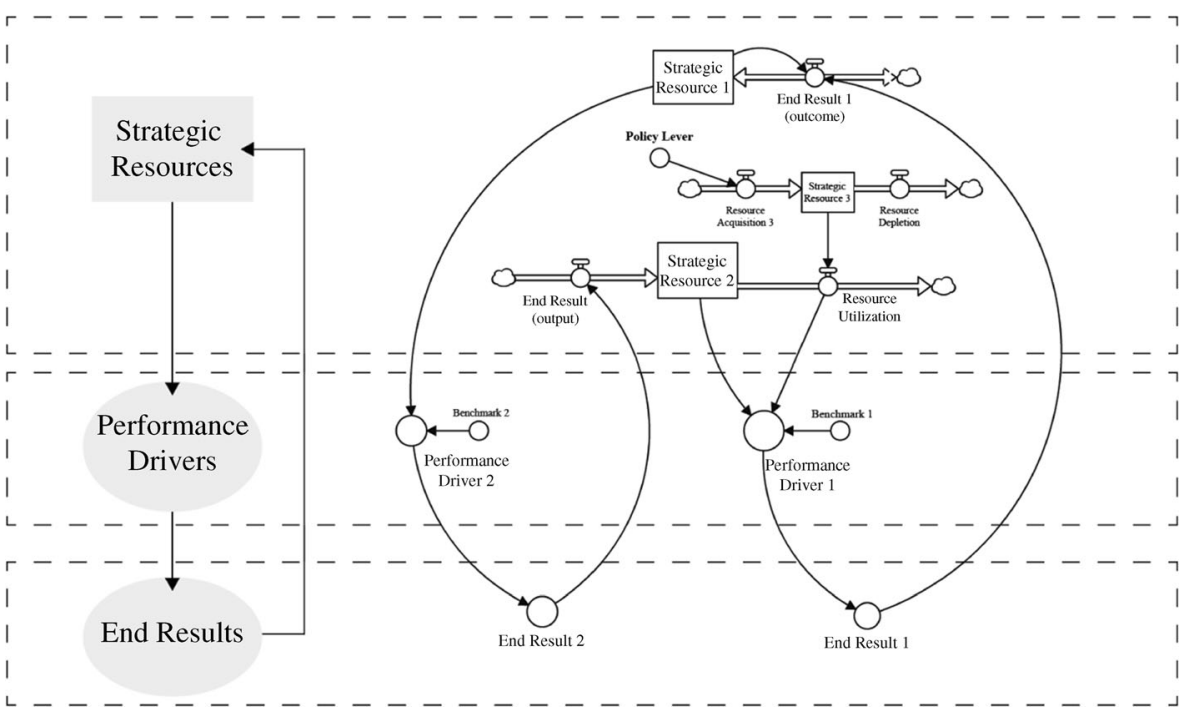

Fig. 2 The dynamic perspective of performance (adapted from Bianchi 2016: 73) 

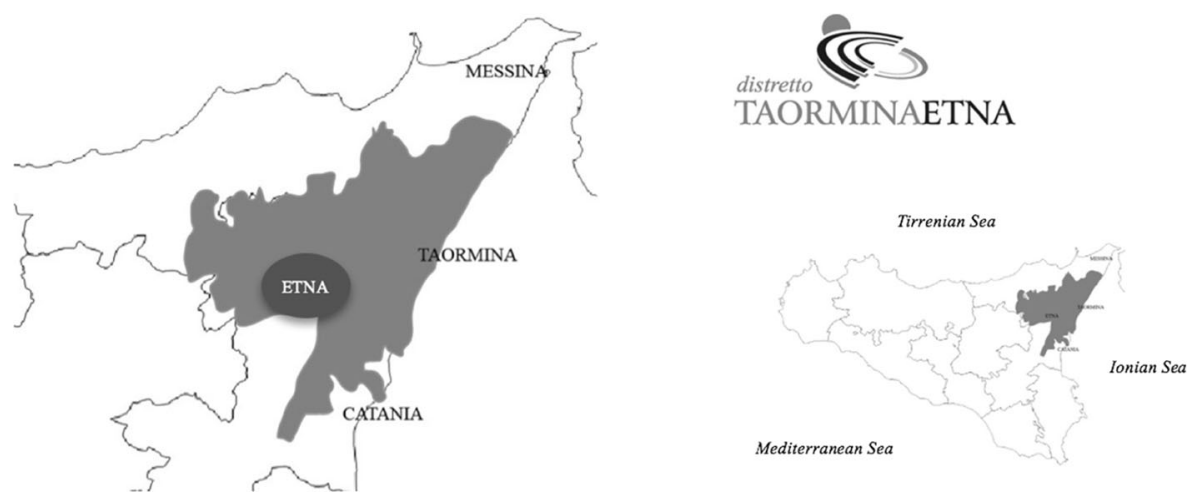

Fig. 3 The geographical area of "Taormina-Etna district"

with the other system's players is a complex task. Maintaining a proper endowment of strategic resources is the only way to develop sustainably. Although intangible resources (i.e. image, reputation, social capital) are difficult to define as well as to measure, they play a significant role in affecting performance. Their unbalanced accumulation and depletion processes can be the result of erroneous policies or just of inertial dynamics. Both need to be addressed, but inherent delays make difficult to perceive the effects generated by decisions. Thus they may cause trade-offs in time and space. DPM provides decision-makers with proper lenses through which they can understand and counteract such phenomena.

\section{Case Study: "Taormina Etna District"}

Since the beginning of the 1990's, Integrated Territorial Projects ${ }^{1}$ (ITPs) defined Italian local development policies. These projects have become a powerful instrument to foster local sustainable development and a vehicle to involve the lowest levels of the Italian governmental in the long-term strategies. In Sicily, many municipalities have created agencies as a form of public-private partnerships aiming at i) coordinating growth strategies; ii) monitoring investments and secure funding from different sources; iii) supporting projects development to capitalize on local resources and tackle those factors limiting the socio-economic growth.

"Taormina Etna district" is the brand for a local development agency that supports firms and municipalities located between Messina and Catania, along the Sicilian East Coast. In its territory, the district includes two famous icons of Sicily: the city of Taormina and the Etna volcano. The area characterized by a coastline includes three natural parks and four natural preserves, it is full of small villages rich in history, local cultures, products and popular traditions. Taormina has been an international icon of tourism since the end of World War II. It has been a destination for luxury tourism, intellectuals and VIPs such as writers, and royalty. Despite this glorious past, due to the

\footnotetext{
${ }^{1}$ ITPs is a modality of implementation of European structural funds. ITPs were introduced for "objective 1" programs and were then extended to the other types of regions. ITPs are a combination of different measures deriving from the structural funds on the basis of local strategies designed by local partnerships. The selection of projects is usually made by regions on the basis of criteria agreed upon with local partnerships.
} 
earthquake of 1968 the Taormina' dolce vita was replaced by a mass tourism: hotels offered rooms to big tour operators and inhabitants started selling their houses and land. Hotels and summer houses crowded messily the pristine land surrounding Taormina. The uncontrolled development, together with the mass tourism, have decayed the image of the city. Taormina holds an enormous heritage, e.g. the ancient theatre of Tauromenion built in the third century BC (Campagna 2009; Rizzo 1927).

Another icon of the area is the Etna volcano that lies above the convergent plate margin between the African Plate and the Eurasian Plate. It is the tallest active volcano in Europe currently 3329 m (10,922 ft.) high. In June 2013, UNESCO added ETNA to the list of World Heritage Sites. It represents a noteworthy attraction for tourists and a great resource for the local economy. The fertile volcanic soils support extensive agriculture, with vineyards and orchards spread across the lower slopes of the mountain and the broad Plain of Catania to the south.

In 2000 the incorporation of the two companies that were leading the ITPs for the local area ("Sviluppo Taormina Etna S.p.a" and "Società Consortile Taormina Etna"), established the "Taormina-Etna district".

The district governance (fig. 4) consists of two agencies for local development owned by the same shareholders, that appoint a CEO. The public shareholders own $51 \%$ of the equity, while the private shareholders the remaining $49 \%$, thus according to the Italian law, the district is a public organization.

The aim of the district is to well manage local, natural, and cultural resources through the enhancement of hospitality infrastructures, the implementation, and promotion of local products and traditions as well as the education of human resources (DTE 2009: 3). To achieve such goals "Taormina-Etna district" has operated through project-based activities aimed at attracting funds from national, regional, and European programs. The district received funds for 5 ITPs trough which it spent more than

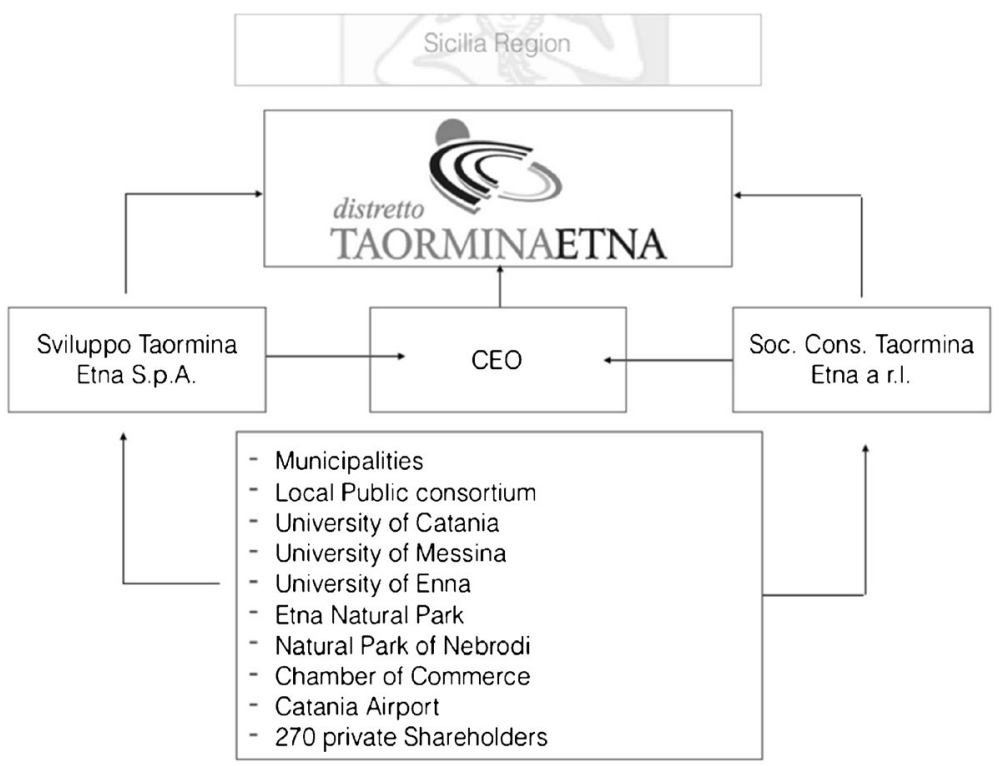

Fig. 4 The "Taormina-Etna district" institutional framework 
EUR150 millions (59\% as public funds, $41 \%$ as private capital). The funds have been used to subsidize businesses, create public infrastructures, and support touristic marketing initiatives (DTE 2015). Figure 5 shows the results of the 5 ITPs as presented by the district administration.

The realization of the ITPs has created new business ventures and has provided opportunities for local entrepreneurs to increase the operations of their firms. The promotional initiatives have generated a certain amount of contacts between the district and the potential market. All of these results are at best output of strategies or indicate just an input acquisition since they represent a pre-requisite to produce value for the local community.

In the next section, the results of the district will be layered up with the performance of the local area, trying to understand whether those results have increased the image of the local area.

\section{Analyzing the Outcome of the Local Area}

This paper aims to frame the sources of the image of a local area through an outcome based dynamic performance management. To this end, the first step is to identify the outcome and to analyze the results achieved by the local area. Essentially, the district has operated as destination agency because the main economic sector of the area is tourisms, and most of the activities are tourism-related. The tourism presence can be taken as measure of the effect of the image. Assuming that there is a causal and direct relationship between the image of the local area and the flow of tourists, the better the experience with the local area, the higher the image of the local area is. An improvement in the image of the local area will cause - ceteris paribus - a higher number of tourists. Figure 6 shows this dynamic hypothesis.

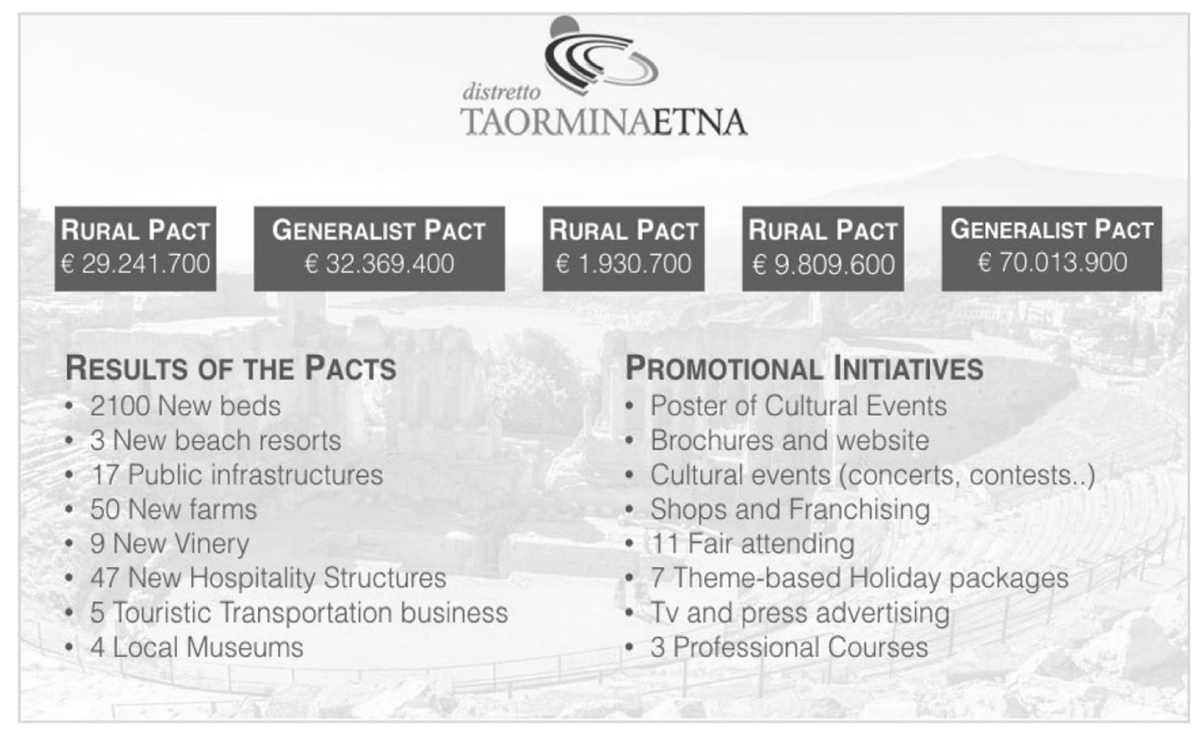

Fig. 5 The results of "Taormina-Etna district" from 2000 to 2015 (source: DTE 2009, 2015) 


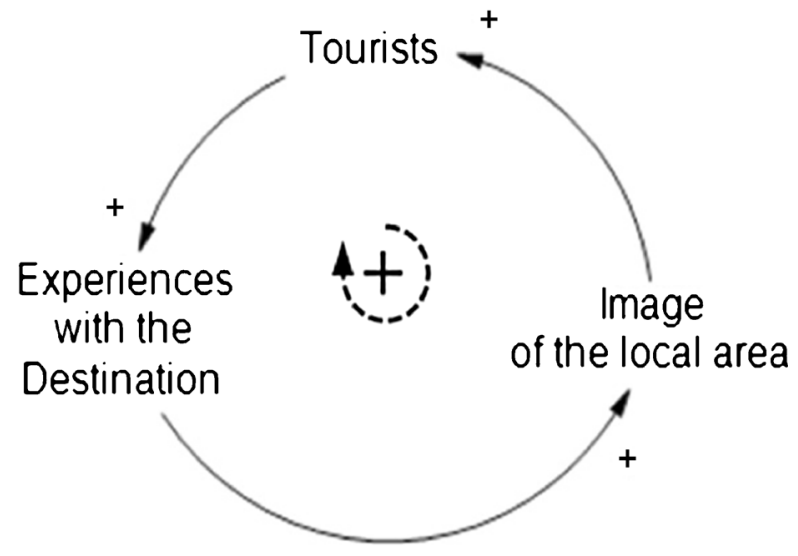

Fig. 6 The development of the image of a tourism destination as based on tourists' experience

Since a tourism destination is a 'product', it can be purchased by only getting there. Especially for potential foreign tourists, travel-oriented social networks, websites with users' reviews play a prominent role in word-of-mouth processes. Local area organizations can only intervene on the factors determining the experience of the visitors at the destination i.e. the room availability in the desired holiday period, the price of the accommodation, the quality of the natural environment, the transportation services and the infrastructure, the cultural attractions, and the advertising.

These aspects are products, services or initiatives suitable to close the gap between the desired strategic positioning of the destination and the current state. They are also outputs of the local area and should be collectively converged toward the outcome.

The region embracing Messina and Catania is the broader area in which "TaorminaEtna district" operates. The research observed the dynamics of tourists and related variables from 2000 until 2014, to understand the impact of the district policies (presented in fig. 5) on the overall results.

From 2000 to 2014 the flow of arrivals and their presence (fig. 7) remained quite stable, while the average residence time (presence divided by arrivals) shows a slight decrease, meaning that people spend less time for a holiday in the area.

Over the same period, the number of hospitality structures have increased significantly (fig. 8.1) especially the so-called non-hotel (B\&Bs, farms for holiday, camping, summer vacation houses), but bed capacity data shows a different pattern. Hotels represent the larger part of the total bed capacity while the non-hotel sector a smaller part.

Figure 8.2 shows the hospitality capacity in terms of bed places, while fig. 8.3 the average number of bed per structure. Comparing fig. 8.1 and fig. 8.2, it emerges that the hotels' average capacity (dashed line in fig. 8.3) has been constant over the years, while the average capacity of the non-hotel (solid line in fig. 8.3) has decayed.

This decay means that a big number of very small structures have been created. Thus, the growth of non-hotel sector (line 2 in fig. 8.1) is primarily in modest structures. The reduction of the average bed capacity in the non-hotel sector had some effects on the holiday length. Due to the increasing number of hospitality structures, hotels have to compete with a plethora of non-conventional accommodation suppliers, which compete aggressively especially after the widespread of internet booking services. They offer farm or winery stays, with many additional services but most often at 


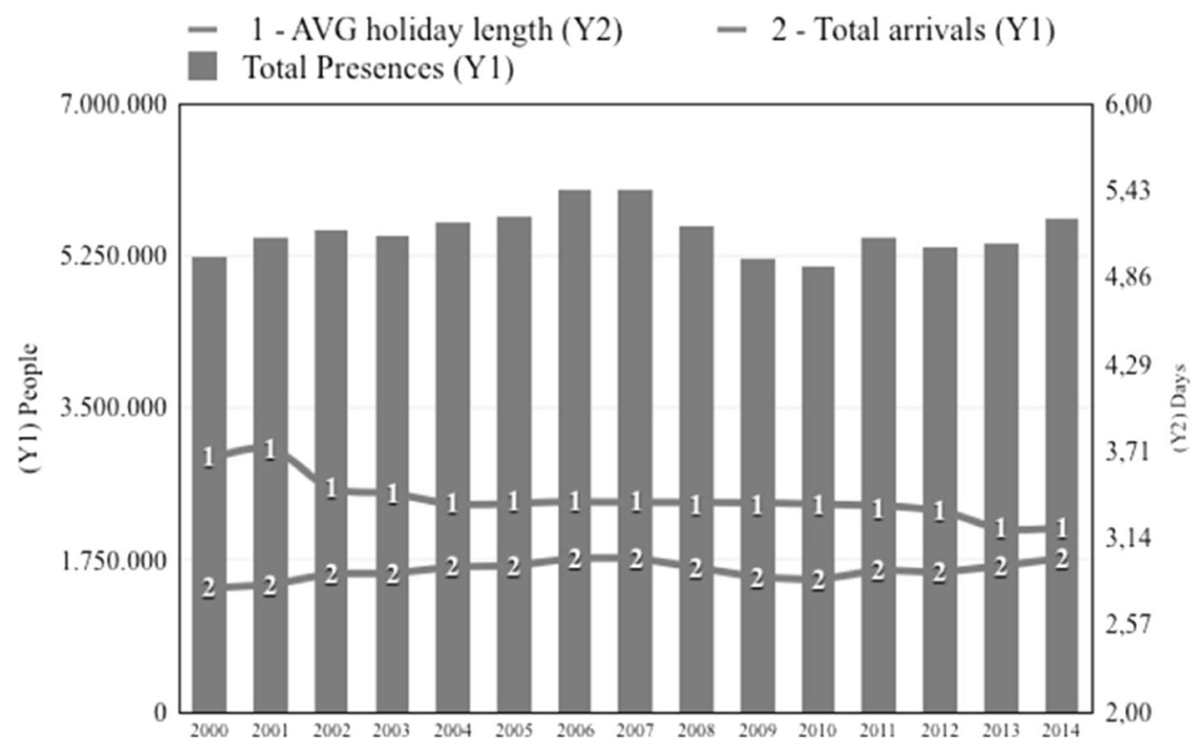

Fig. 7 Tourist arrivals, presence and average holiday length (data source: Osservatorio Turistico, Dipartimento turismo, sport e spettacolo Regione Sicilia)

half the price of hotels, since they have a less rigid cost structure. This phenomenon has caused that: i) hotels start lowering prices to cope with competition, while non-hotel structures start raising prices to get enough returns for the services they offer (only a limited number of room, swimming pool, beauty spa). Consequently, hotel prices (from
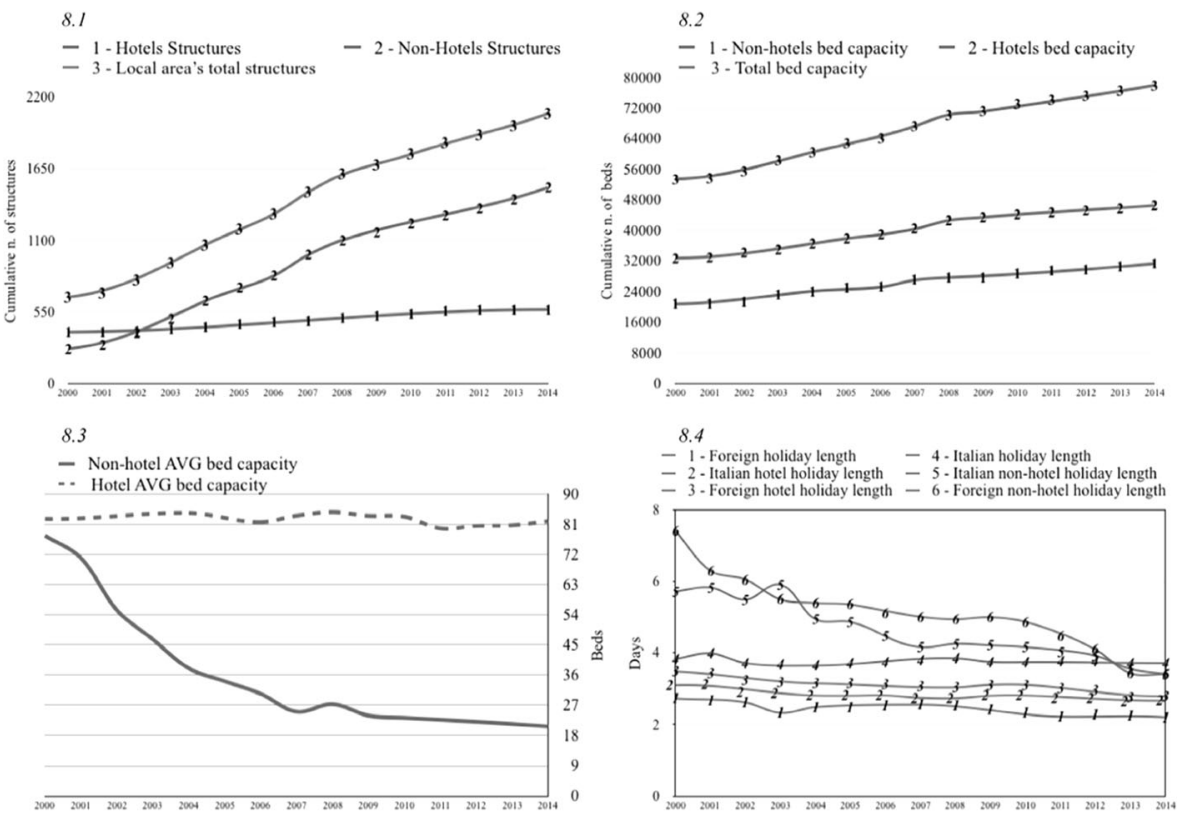

Fig. 8 Total hospitality structures, non-hotel, and hotel structures (8.1). Hotels and non-hotels bed capacity (8.2). The average number of bed per structure (8.3). The average holiday length per tourist origin and type of structure (8.4). (data source: Osservatorio turistico, dipartimento turismo, sport e spettacolo Regione Sicilia) 
above) and non-hotel price (from below) are going to converge in the next future. This competition may compromise the sustainability of both big and small structures, which are necessary for a destination. The reduction of the average holiday length (fig. 8.4) might be due to a competition between hotel and non-hotel structures. Based on the dynamics shown in fig. 8.4, it emerges that the local area is losing his appeal as "long-stay" holiday destination. All-average residence times are decreasing, the non-hotels one particularly.

Tourism development cannot be evaluated only through the dynamics of accommodation services. An important indicator of the tourism movement, and by consequence of local attractiveness, is the dynamics of museums visitors. The museum guests (line 3 in fig. 9) and the ticket-per-tourist (line 1 in fig. 9) as the figure portrays are quite stable. In addition, as the number of visitors is constant, revenues have increased significantly due to a rise in ticket pricing. It is important to notice that the "ancient theatre of Taormina" weights about the $60 \%$ of total visitors and the $80 \%$ of total revenues in the district. It means that the Taormina theatre can be considered the only heritage building visited in the area.

After having commented the results of the local area, it is possible to draw some preliminary conclusions. The flow of tourists has been quite constant, the local museums are not visited except the "ancient theatre of Taormina," the strong competition among accommodation structures may compromise the sustainability of the sectors. Based on the above evidence one may argue that for the local area, tourism performance has not been improved by the policies and the investments realized from 2000 to 2014 by the "Taormina-Etna district."

\section{Modeling Local Area Image through an Outcome-Based Dynamic Performance Management View}

As Forrester (1992: 56) emphasized the information for understating the causal relationships responsible for the observed dynamics can be attained from different sources: from decision-makers' "mental database" to numerical databases. Likewise, as Yin (2013: 116) put it, "no single source has a complete advantage", therefore many sources should be used.

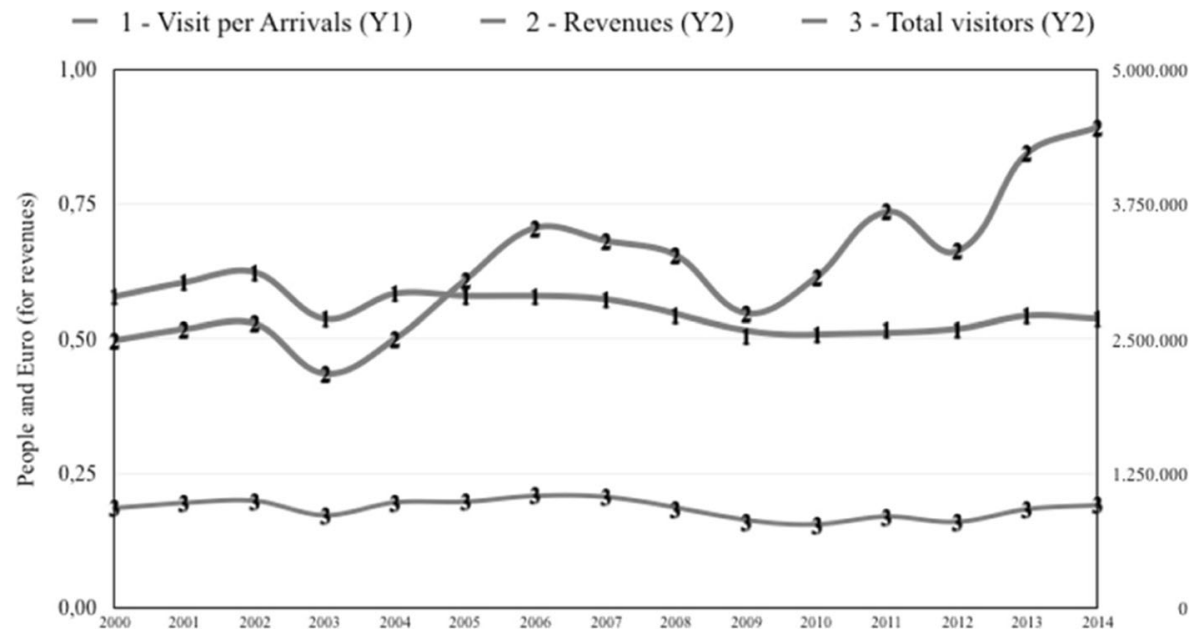

Fig. 9 Museum tickets sold, museum revenues, and ticket-per-tourist (data source: Osservatorio turistico, dipartimento turismo, sport e spettacolo Regione Sicilia) 
Table 1 reports the sources of evidence collected (the size of the sample in square brackets): interviews with local decision-makers and semi-structured interviews with local entrepreneurs have been performed; district documents, statistical databases have been read; comments and feedbacks on tourism- and travel-oriented websites have been coded. The table also shows the purpose of the several inquiries and the weak points that arose.

The causal relationships that constitute the model (fig. 10) have emerged by the analysis of interviews, conference reports, and archival records. The model synthesizes four synthetic factors influencing the image of the local area.

Defining the four constructs:

- Level of tourism development denotes the position of the destination in a specific phase of the evolution cycle. It reflects the growth rate of tourism in the area by considering arrivals, presence, and the average length of the holiday. Such a measure influences the strategies of local organizations as the destination goes through its cycle. The more tourists in the area, the higher the willingness of people to invest in the local area will be. Those investments may change the local area image.

- Fit of contextual attributes depends on the local promotion, cultural and environmental policies. It synthesizes the use of the land, natural attractions, cultural attractions, artificial facilities, and easiness to visit the attractions around the places in which the tourists resides. It captures how the tourists live in and experience with the local area.

- Strength of identity stands for the promotion of typical local products, local heritage and local traditions towards the tourists. It also includes the degree of integration between the producers, if they use local raw materials in producing their products or if they share innovation project. Strength of identity tries to illustrate the extent by which the place talks about its history and values through museums, products, and food.

Table 1 The sources of evidence: target of the inquiry, purpose, and weaknesses of the sources

\begin{tabular}{|c|c|c|c|}
\hline $\begin{array}{l}\text { Sources of } \\
\text { evidence }\end{array}$ & Target & Purpose & Weaknesses \\
\hline Conference & $\begin{array}{l}\text { District results } \\
\text { presentation } \\
{[1 \text { conference }]}\end{array}$ & $\begin{array}{l}\text { Knowledge of district purpose, area's } \\
\text { boundaries and partner }\end{array}$ & $\begin{array}{l}\text { General context, no debate, } \\
\text { only } \\
\text { positive data commented }\end{array}$ \\
\hline Open Interview & $\begin{array}{l}\text { CEO of the } \\
\text { district } \\
{[1 \text { interview }]}\end{array}$ & $\begin{array}{l}\text { Knowledge of local area's strategies, } \\
\text { policies and stakeholders. }\end{array}$ & $\begin{array}{l}\text { Reflexivity of the discourse } \\
\text { Bias due to the poorly } \\
\text { articulated questions }\end{array}$ \\
\hline Documentation & $\begin{array}{l}\text { District } \\
\quad \text { publications } \\
{[2 \text { issues }]}\end{array}$ & $\begin{array}{l}\text { Understating ITPs, strategies, detailed } \\
\text { actions, and initiatives }\end{array}$ & $\begin{array}{l}\text { Only quantitative input and } \\
\text { output measure. }\end{array}$ \\
\hline $\begin{array}{l}\text { Semi structured } \\
\text { Interviews }\end{array}$ & $\begin{array}{l}\text { Local } \\
\text { Entrepreneurs } \\
\text { [20 interviews }]\end{array}$ & $\begin{array}{l}\text { Understanding the business strategies, } \\
\text { local production, and the } \\
\text { destination issues. }\end{array}$ & $\begin{array}{l}\text { Political and/or context } \\
\text { biases } \\
\text { Inaccuracy due to the time }\end{array}$ \\
\hline $\begin{array}{l}\text { Archival Records } \\
\text { (tripadvisor[dot]it) }\end{array}$ & $\begin{array}{l}\text { Tourists } \\
\text { [100 records } \\
\text { coded }]\end{array}$ & $\begin{array}{l}\text { Understanding the visitors' } \\
\text { perception of the destination. The } \\
\text { weaknesses and the strengthless }\end{array}$ & $\begin{array}{l}\text { Long-time span and different } \\
\text { settings. Not for the } \\
\text { purpose. } \\
\text { Incomplete records }\end{array}$ \\
\hline $\begin{array}{l}\text { Statistical } \\
\text { Database }\end{array}$ & Numerical data & Obtain the official data about main variables & $\begin{array}{l}\text { Generality } \\
\text { Not self-explaining }\end{array}$ \\
\hline
\end{tabular}




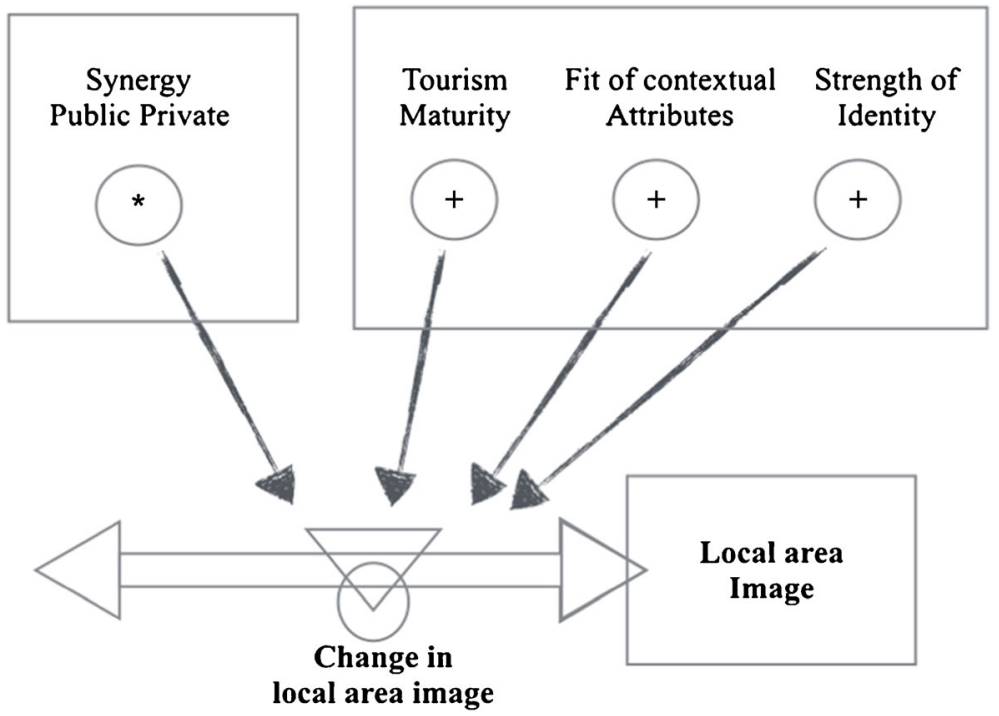

Fig. 10 The sources of the local area image (simplified version of the SD model)

- Synergy between public and private sector means that public and private organizations run projects aimed at improving their own respective results, such as networking activity among hotels, restaurants and museums; websites and info-points to share information about the destination; a unique label to certifies the local production.

The factors from 1 to 3 are additive, while the synergy between public and private works as multiplier of the first three elements.

Table 2 links the 1st-level performance drivers with 2nd-level, connecting their measures. The research adopted a deductive-inductive approach to identify the performance drivers. The theoretical approach discussed in the first part of the work, served as lens through which carry out the semi-structured interviews and to analyze the other sources of information exposed in Table 1 since "inductive modelling [...] sought for the solution to a specific problem" (Größler 2008: 468).

After having defined the performance drivers, the next section of the paper will discuss how DPM may support decision-makers in managing the image of a local area and to improve the local area's performance sustainably.

\section{Sketching a Dynamic Performance Management Chart to Manage the Local Area Image}

An outcome-based DPM perspective of the image of a local area emphasizes threelayers: from end results back to strategic resources, through performance drivers.

The outcome-based analysis of the "Taormina-Etna district" aimed to frame the sources of the local area image through performance drivers that may trigger performance improvement.

The model is composed of two fundamental equations, where the image is modelled as adaptive expectation through the exponential smoothing of its source. In this way, the 
Table 2 Performance Drivers (bold, abbreviation in parenthesis), definition (italic), and measure

\begin{tabular}{|c|c|c|}
\hline 1st-level Performance Drivers & 2nd-level Performance Drivers & Measures \\
\hline \multirow{3}{*}{$\begin{array}{l}\text { Level of Tourism development } \\
\text { (TD) }\end{array}$} & Tourist fractional growth rate (TGR) & $\%$ \\
\hline & Bed fractional growth rate (BGR) & $\%$ \\
\hline & Weighted average holiday length (WAHL) & days \\
\hline \multirow{3}{*}{$\begin{array}{l}\text { Fit of contextual attributes } \\
\quad \text { (CA) }\end{array}$} & Average structure's size (AVG-ST-SIZE) & $\mathrm{bed} /$ structure \\
\hline & $\begin{array}{l}\text { Urban Density (UD) } \\
\text { urbanized land/total land }\end{array}$ & Dimensionless \\
\hline & $\begin{array}{l}\text { Attraction density }(\mathrm{AD}) \\
\text { total attraction/local area surface }\end{array}$ & Attractions $/ \mathrm{m}^{2}$ \\
\hline \multirow[t]{3}{*}{ Strength of identity (I) } & $\begin{array}{l}\text { Local-oriented attraction ratio (LAR) } \\
\text { n. of local-oriented attraction/total attraction }\end{array}$ & Dimensionless \\
\hline & $\begin{array}{l}\text { Typical labeled product ratio (TYP) } \\
\text { n. of firms producing labeled products/total firms }\end{array}$ & Dimensionless \\
\hline & $\begin{array}{l}\text { Integration of supply chain (ISC) } \\
\text { n. of restaurants using local products/total restaurants }\end{array}$ & Dimensionless \\
\hline \multirow[t]{3}{*}{$\begin{array}{l}\text { Synergy Between Public and } \\
\text { Private sector (SYN) }\end{array}$} & $\begin{array}{l}\text { Integration of innovation i.e. internationalization, R\&D, } \\
\text { Know How (INN) } \\
\text { n. of firms sharing a project/ total firms }\end{array}$ & Dimensionless \\
\hline & $\begin{array}{l}\text { Density and scope of Touristic circuit (DSTC) } \\
n \text {. of affiliated activities*category of activities*(surface of } \\
\text { covered municipality/total land surface) }\end{array}$ & Dimensionless \\
\hline & $\begin{array}{l}\text { Strategic dialogue in the local area (STDLG) } \\
\text { n. of agreement achieved/total agreement }\end{array}$ & Dimensionless \\
\hline
\end{tabular}

model - as the simplest information stock does - adjusts the belief to the actual value of the input variable ${ }^{2}$ gradually. The Change in the image of the local area (1) updates the perceived value of the Local area image (2), according to a certain perception time.

$$
\text { Change in local area image }=\frac{(((\mathrm{TD}+\mathrm{CA}+\mathrm{I}) * S Y N)-\text { Local area Image })}{\text { Time to change image }}
$$

$$
\text { Local area image }=\int_{0}^{t} \text { Change in local area image } * D T+\text { Local area image }_{t 0}(2)
$$

As equation $^{3}$ (1) shows, the four 1st-level performance drivers affect the "change in local area image". The four first level performance drivers are the multiplication of the relative normalized 2 nd-level performance drivers. Indeed, they compare a current state of the system with a given benchmark (i.e. a target value, a competitor value or a desired level). The following equations present the 1 st-level performance drivers as composed by the 2 nd-level performance drivers. ${ }^{4}$ Equations from (3) to (6) represent the 1st-level performance drivers as part of an SD model.

\footnotetext{
${ }^{2}$ The input value is the sum of three 1 st-level performance drivers, multiplied by the synergy between public and private sector.

3 These abbreviations can be found in table 2

${ }^{4}$ In an SD model, those drivers normalized through a benchmark value. This value works for a nondimensional input to the table lookup function that converts this input into a min-max scalable output.
} 
Level of Tourism development $(T D)$

$$
=\left(\frac{T G R}{\text { Target } T G R}\right) *\left(\frac{B G R}{\text { Sicilian } B G R}\right) *\left(\frac{\text { WAHL }}{\text { Target WAHL })}\right.
$$

Fit of contextual attributes $(C A)$

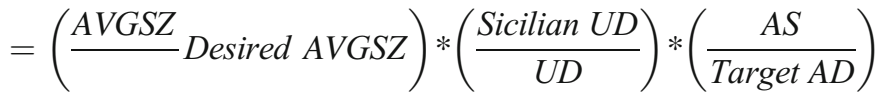

$$
\begin{aligned}
& \text { Strenght of local identity }(I) \\
& \quad=\left(\frac{\text { LAR }}{\text { Target LAR }}\right) *\left(\frac{\text { TYP }}{\text { Desired TYP }}\right) *\left(\frac{I S C}{\text { Desired ISC }}\right)
\end{aligned}
$$

Synergy between public and private $(S Y N)$

$$
=\left(\frac{I N N}{\text { Desired INN }}\right) *\left(\frac{D S T C}{\text { Desired DSTC }}\right) *\left(\frac{\text { STDLG }}{\text { Target STDLG })}\right.
$$

Once the performance drivers are pointed out, the linked strategic resources are made explicit. Thus, the leverage points upon which the decision-makers can intervene to affect the outcome - through the performance drivers - are clearly revealed. In this way, each decision-maker may identify those strategic resources he manages and understand which output he should improve.

As fig. 11 shows, the change in the local area image will increase the perceived local area image, which in turn, - all other things being equal - will cause an increase in tourism arrivals; an increasing number of tourists means more value for the local area to support the policies.

The end result is affected by four 1st-level performance drivers, which comprise twelve 2nd-level performance drivers that in turn depend on the strategic resources. As the DPM chart (fig. 11) clearly shows, it is not possible to affect performance drivers directly since they compare a current state of performance with a given benchmark. It is, rather, possible to design policies to affect the upstream strategic resources in order to influence the drivers, and finally to improve the outcome.

The driver "fit of contextual attributes" synthesizes the suitability of contextual attributes with tourism activities. To increase such drivers, it is necessary to increase the strategic resources "attraction" (i.e. by renovation of heritage building, by opening museums). On the other side an increase in the number of building (i.e. houses for holidays, apartment building for citizens) also increases urban density and it will reduce the "fit of contextual attributes." Policy makers may strengthen local identity by increasing the strategic resource "attractions" that relates to local history and cultures, 


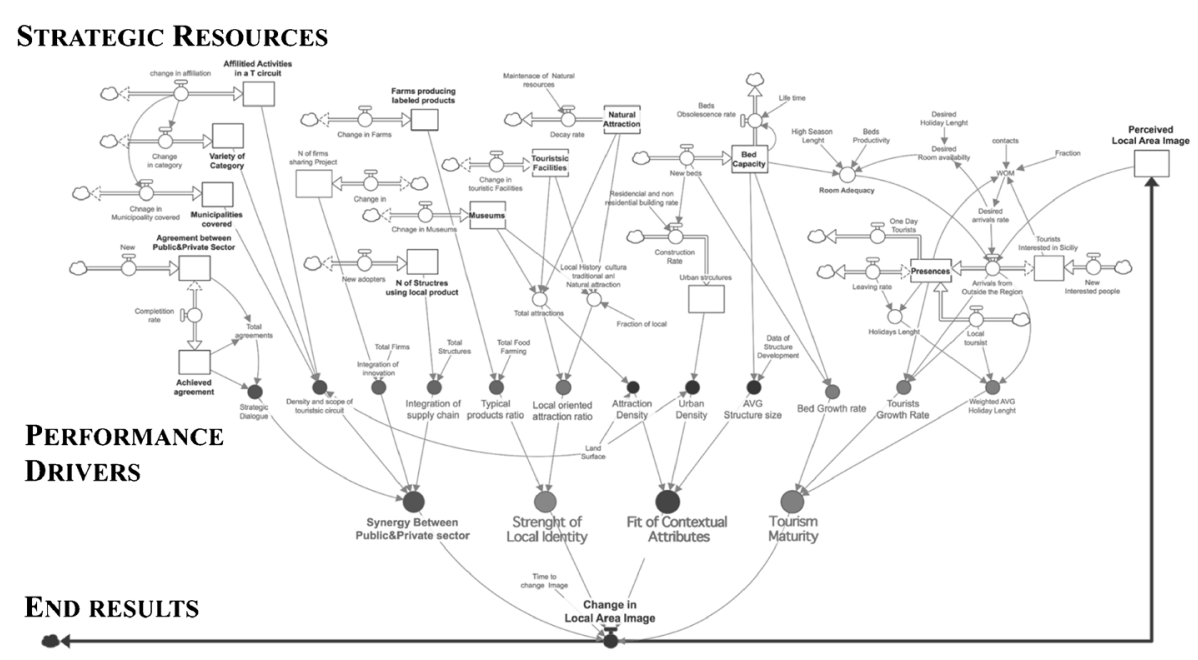

Fig. 11 A Dynamic Performance Management view of the image of a local area

likewise the number of firms producing typical products. The performance driver "Level of Tourism development" captures the lifecycle of the destination by considering the growth rate of tourists, the weighted average of the holiday length, and the bed growth rate. This measures gives suggestions about the need of new/better clear destination positioning.

The most effective way to improve image is through synergy between the public and private sectors. It compounds the policy-makers' results in the other three driving factors. If the number of attractions is increased but that is not linked with accommodation services and transportation facilities or not listed on tourism websites, the image can only be slightly improved. In the same fashion, the firms producing typical products should supply local restaurants, jointly run projects (i.e. R\&D, internationalization, export consortia), and together with public institutions outline strategic plans for the local area. Increasing the synergy between both private and public sector will spread out the positive effect throughout the system.

By following the discussion of the model, it is possible to give some policy suggestions to decision-makers. They may want to consider a more balanced approach to image management, which could include all or most of those performance drivers described in this research. They should manage the size of the hospitality structure, avoiding both super small structures that raise the per-night prices and super big hotels that increase soil erosion and concentrate tourists in one place. Local history and tradition should be more connected with natural attractions (beaches and mountains) and leisure, and typical products should be standard ingredients in local restaurants. Policy-makers should network the small municipalities and the private sectors in a more comprehensive tourist package, increasing the scope of the journey across the local area. Before moving to the findings, it is important to make clear the limitations of the model. According to Sterman (2002: 513), "the most important assumptions of a model are not in the equations, but what's not in them; not in the documentation, but unstated; not in the variables on the computer screen, but in the blank spaces around them." The model here discussed is necessarily limited regarding the number of 
feedback loops described, because a large number of factors should be included and taken into account to map all the relevant feedbacks. Weaknesses involves some of the linkages between each organization and the entire system. For that reason, the DPM analysis presented here considers only the main feedback loop involving the performance drivers affecting the end-result under investigation.

\section{Conclusions}

Two main approaches have traditionally investigated the relationships between place and image: the $\mathrm{CoO}$ effect and the competitive identity framework. Recent studies highlight that country image represents only one of the "extrinsic cues" able to influence the choice behaviour of consumers. In addition, other research links the $\mathrm{CoO}$ effect to specific product characteristics or to portion of the value chain. The competitive identity theory contends that the image of a place is associated with strategy, substance and symbolic actions, and that "nation branding" is not merely a marketing concern. Despite the number of publications, perspectives for further research on the relationship between place and image are many and of great interest, especially if further studies will develop both theoretical and managerial point of view on the issue and they will adopt qualitative techniques with explanatory purposes.

To frame the image of a local area this article has adopted and endogenous perspective and a qualitative research strategy, which differentiate this work from established studies on place-image relationships. It also provides a basis for discussion and development of the research. After having gone through an outcome-based interinstitutional DPM perspective, it is possible to cover the issues raised in this work. The study noticed that the practice of "Taormina-Etna district's" performance measurement is mainly composed of input indicators which do not provide any insights regarding performance to policy-makers. The paper also reviewed the dynamics of tourismrelated variables as results of the local area from 2000 to 2014. Both tourism arrivals and presence have not increased while the holiday length has decreased on average. Particularly, the stay of non-hotel guests has decayed from six to less than three days on average. Also, the competition within the hospitality sector may compromise the sustainability of both hotel and non-hotel structures.

The study presented in this article emphasizes the need for a DPM approach to support decision-makers in framing the sources of the image of a local area. The DPM chart, as a result of a case study, identifies four main driving factors: the level of tourism development, the fit of contextual attributes, the strength of identity, and the synergy between public and private sector. These performance drivers - in combination with twelve indicators - enable decision-makers to adopt performance measures which give insights and policy recommendation on how to connect institutional outputs with interinstitutional outcomes. The DPM chart connects institutional outputs with the interinstitutional outcome. However, the model discussed in this work needs to be further developed into a simulation model. Such an advancement may help policy-makers in understanding the dynamics of accumulation and depletion processes of strategic resources and in assessing the sustainability of alternative policies. Through dynamic simulation, one may show how performance drivers interact, influence each other, and behave over time. 


\section{References}

Ackoff, R. L. (1977). Optimization + objectivity= opt out. European Journal of Operational Research, 1(1), 1-7. https://doi.org/10.1016/S0377-2217(77)81003-5

Andéhn, M., \& Berg, P. O. (2011). Place of origin effects - from nations to cities : A conceptual framework based on a literature review. Paper presented at the 2 nd international place branding conference, Bogotá.

Anholt, S. (2007). Competitive identity. Basingstoke: Palgrave Macmillan UK. https://doi.org/10.1057 /9780230627727

Anholt, S. (2011). Beyond the nation brand:the role of image and identity in international relations. Exchange: The Journal of Public Diplomacy, 2(1), 1-7.

Anselmi, L. (2014). Percorsi aziendali per le pubbliche amministrazioni: Edizione rivista ed ampliata. Torino: Giappichelli.

Begg, I. (1999). Cities and competitiveness. Urban Studies, 36(5/6), 795-809. https://doi.org/10.1080 /0042098993222

Bertoli, G., \& Resciniti, R. (2013). International marketing and the country of origin effect. Cheltenham: Edward Elgar Publishing. https://doi.org/10.4337/9781781955611

Bianchi, C. (2004). Sistemi di programmazione e controllo per l'azienda «Regione». Milano: Giuffrè.

Bianchi, C. (2010a). Improving performance and fostering accountability in the public sector through system dynamics modelling: From an 'external'to an 'internal'perspective. Systems Research and Behavioral Science, 27(4), 361-384. https://doi.org/10.1002/sres.1038

Bianchi, C. (2010b). Improving performance and fostering accountability in the public sector through system dynamics modelling: From an 'external' to an 'internal' perspective. Systems Research and Behavioral Science, 27(4), 361-384. https://doi.org/10.1002/sres.1038

Bianchi, C. (2012). Enhancing performance management and sustainable organizational growth through system-dynamics modelling. In S. N. Grösser \& R. Zeier (Eds.), Systemic management for intelligent organizations (pp. 143-161). Berlin: Springer. https://doi.org/10.1007/978-3-642-29244-6_8

Bianchi, C. (2016). Dynamic performance management. Cham: Springer International Publishing. https://doi. org/10.1007/978-3-319-31845-5

Bianchi, C., \& Rivenbark, W. C. (2012). Using system dynamics to enhance performance management in local government: An application to residential refuse collection, 2012 APPAM Fall Research Conference, November.

Bianchi, C., \& Tomaselli, S. (2015). A dynamic performance management approach to support local strategic planning. International Review of Public Administration, 20(4), 370-385. https://doi.org/10.1080 /12294659.2015.1088687

Borgonovi, E. (2002). Principi e sistemi aziendali per le amministrazioni pubbliche. Milano: EGEA.

Bouckaert, G., \& Halligan, J. (2007). Managing performance: International comparisons. New York: Routledge.

Bursi, T., \& Galli, G. (2012). Marketing internazionale. Milano: McGraw-Hill Education.

Campagna, L. (2009). Urbanistica dei centri siciliani d'altura in età ellenistica: il caso di Tauromenion. Eis acra: $1000-1022$.

Cavenago, D., \& Trivellato, B. (2010). Organising strategic spatial planning: experiences from Italian cities. Space and Polity, 14(2), 167-188. https://doi.org/10.1080/13562576.2010.505795

Davidsen, P. (1991). The structure-behavior graph. Cambridge: The System Dynamics Group, MIT.

Dinnie, K. (2004). Country-of-origin 1965-2004: a literature review. Journal of Customer Behaviour, 3(2), 165-213. https://doi.org/10.1362/1475392041829537

DTE. (2009). Distretto Taormina Etna: Luglio 2001 - Aprile 2009. Catania.

DTE. (2015). The Museum of the Etna's historical identity. Catania.

Forrester, J. W. (1961). Industrial dynamics. Cambridge: M.I.T. Press.

Forrester, J. W. (1969). Urban dynamics. Cambridge: MIT press.

Forrester, J. W. (1992). Policies, decisions and information sources for modeling. European Journal of Operational Research, 59(1), 42-63. https://doi.org/10.1016/0377-2217(92)90006-U

Fruchter, G. E., Jaffe, E. D., \& Nebenzahl, I. D. (2006). Dynamic brand-image-based production location decisions. Automatica, 42(8), 1371-1380. https://doi.org/10.1016/j.automatica.2006.01.020

Gertner, D., \& Kotler, P. (2004). How can a place correct a negative image? Place Branding and Public Diplomacy, 1(1), 50-57. https://doi.org/10.1057/palgrave.pb.5990004

Ghaffarzadegan, N., Lyneis, J., \& Richardson, G. P. (2011). How small system dynamics models can help the public policy process. System Dynamics Review, 27(1), 22-44. 
Größler, A. (2008). System dynamics modelling as an inductive and deductive endeavour. Comment on the paper by Schwaninger and Grösser. Systems Research and Behavioral Science, 25(4), 467-470. https://doi.org/10.1002/sres.908

Größler, A. (2010). Policies, politics and polity: comment on the paper by Bianchi. Systems Research and Behavioral Science, 27(4), 385-389. https://doi.org/10.1002/sres.1051

Han, C. M. (1989). Country image: halo or summary construct? Journal of Marketing Research, 26(2), 222. https://doi.org/10.2307/3172608

Han, C. M. (1990). Testing the role of country image in consumer choice behaviour. European Journal of Marketing, 24(6), 24 40. https://doi.org/10.1108/EUM0000000000609

Ho, A. T. K., \& Ni, A. Y. (2005). Have cities shifted to outcome-oriented performance reporting?-A content analysis of City budgets. Public Budgeting \& Finance, 25(2), 61-83. https://doi.org/10.1111/j.02751100.2005.00361.x

Johansson, J. K. (1989). Determinants and effects of the use of "made in" labels. International Marketing Review, 6(1), 47-58.

Kotler, P., \& Gertner, D. (2011). A place marketing and place branding perspective revisited. In N. Morgan, A. Pritchard, \& R. Pride (Eds.), Destination brands: Managing place reputation (pp. 33-53). Oxford: Butterworth-Heinemann. https://doi.org/10.1016/B978-0-08-096930-5.10003-5

Kotler, P., Ravazzi, G., \& Salinas, G. (1978). Al servizio del pubblico. Milano: Etas.

Kotler, P., Haider, D., \& Rein, I. (1993). There's no place like our place! The marketing of cities, regions, and nations. The Futurist, 27(6), 14-21.

Lane, D. C. (1995). The folding star: a comparative reframing and extension of validity concepts in system dynamics. In T. Shimada \& K. Saeed (Eds.), International system dynamics conference (Vol. vol. 1, pp. 111-130). Tokyo: Gakushuin University.

Lane, D. C. (2012). What is a 'policy insight'? Systems Research and Behavioral Science, 29(6), 590-595. https://doi.org/10.1002/sres.2148

Martin, I. M., \& Eroglu, S. (1993). Measuring a multi-dimensional construct: country image. Journal of Business Research, 28(3), 191-210. https://doi.org/10.1016/0148-2963(93)90047-S

Matarazzo, M. (2012). Country of origin effect: Research evolution, basic constructs and firm implications. In G. Bertoli \& R. Resciniti (Eds.), International marketing and the country of origin effect: The global impact of 'made in Italy' (pp. 23-42). Cheltenham: Edward Elgar.

Meyer, H.-D. (2002). From "loose coupling" to "tight management"? Making sense of the changing landscape in management and organization theory. Journal of Educational Administration, 40(6), 515520. https://doi.org/10.1108/09578230210454992

Meyer, J. W., \& Scott, W. R. (1983). Organizational environments: Ritual and rationality. Beverly Hills: Sage.

Morecroft, J. D. W. (2015). Strategic Modelling and Business Dynamics: A feedback systems approach. Cornwall: Wiley. https://doi.org/10.1002/9781119176831

Morecroft, J., Sanchez, R., \& Heene, A. (2002). Systems perspectives on resources, capabilities and management processes. Oxford: Pergamon.

Morgan, N., Pritchard, A., \& Pride, R. (2004). Destination branding: Creating the unique destination proposition. Oxford: Elsevier Butterworth-Heinemann.

Morgan, N., Pritchard, A., \& Pride, R. (2012). Destination brands. Managing place reputation. Oxford: Taylor \& Francis.

Moxnes, E. (2004). Misperceptions of basic dynamics: The case of renewable resource management. System Dynamics Review, 20(2), 139-162. https://doi.org/10.1002/sdr.289

Papadopoulos, N. G., \& Heslop, L. (1993). Product-country images: Impact and role in international marketing. New York: International Business Press.

Peterson, R. A., \& Jolibert, A. J. (1995). A meta-analysis of country-of-origin effects. Journal of International Business Studies, 26(4), 883-900. https://doi.org/10.1057/palgrave.jibs.8490824

Porter, M. E. (1995). The competitive advantage of the inner city. Harvard Business Review, 73(3), 55-71.

Porter, M. E. (2011). Competitive advantage of nations: Creating and sustaining superior performance. New York: Free Press.

Rizzo, P. (1927). Tauromenion (Taormina). Storia, topografia, monumenti, monete, Riposto.

Roth, M. S., \& Romeo, J. B. (1992). Matching product catgeory and country image perceptions: A framework for managing country-of-origin effects. Journal of International Business Studies, 23(3), 477-497. https://doi.org/10.1057/palgrave.jibs.8490276

Roth, K. P. Z., Diamantopoulos, A., \& Montesinos, M. Á. (2008). Home country image, country brand equity and consumers' product preferences: an empirical study. Management International Review, 48(5), 577602. https://doi.org/10.1007/s11575-008-0031-y

Scott, W. R. (2003). Organizations: rational, natural, and open systems. Englewood Cliffs: Prentice-Hall. 
Senge, P. M., \& Forrester, J. W. (1980). Tests for building confidence in system dynamics models. TIMS Studies in management sciences, 14(1980), 209-228.

Simon, H. A. (1957). Models of man: Social and rational. New York: Wiley.

Sterman, J. D. (1989). Modeling managerial behavior: Misperceptions of feedback in a dynamic decision making experiment. Management Science, 35(3), 321-339. https://doi.org/10.1287/mnsc.35.3.321

Sterman, J. (2000). Business dynamics: systems thinking and modeling for a complex world. Boston: Irwin/ McGraw-Hill.

Sterman, J. D. (2002). All models are wrong: reflections on becoming a systems scientist. System Dynamics Review, 18(4), 501-531. https://doi.org/10.1002/sdr.261

Verlegh, P. W., \& Steenkamp, J.-B. E. (1999). A review and meta-analysis of country-of-origin research. Journal of Economic Psychology, 20(5), 521-546. https://doi.org/10.1016/S0167-4870(99)00023-9

Weick, K. E. (1976). Educational organizations as loosely coupled systems. Administrative Science Quarterly, 21(1), 1-19. https://doi.org/10.2307/2391875

Wolstenholme, E. F. (1990). System enquiry: a system dynamics approach. West Sussex: Wiley.

Wolstenholme, E. F. (1999). A patient flow perspective of UK health services: Exploring the case for new" intermediate care" initiatives. System Dynamics Review, 15(3), 253-271. https://doi.org/10.1002 /(SICI)1099-1727(199923)15:3<253::AID-SDR172>3.0.CO;2-P

Yin, R. K. (2013). Case study research: Design and methods. Thousand Oaks: SAGE Publications.

Vincenzo Vignieri is Research Assistant at the University of Palermo (Italy), and Research Fellows at CED4 System Dynamics group - University of Palermo. He holds an international Ph.D. in Business and Public Management. His research in Public Management focuses mainly on the design and the implementation of performance management system to enhance collaborative governance in local government. He uses System Dynamics methodology to make explicit cause-and-effect relationships between relevant variables underlying the investigated phenomena. 